\title{
Media jako forma przedstawień zbiorowych polityki i jej teoriopoznawcze uwarunkowania
}

\section{Media a obrazy rzeczywistości}

Z achowanie się mediów na rynku komunikacji publicznej umożliwia wyodrębnienie dwu typów przekazów, a mianowicie skupionych na informacji bądź na jawnej lub zawoalowanej perswazji. To pokazuje również, że media informacyjno-publicystyczne mogą starać się nie tylko faktualnie, niejako dokumentalnie odzwierciedlać i rzeczowo komentować poważną i zwykle złożoną rzeczywistość polityczną. Ale mogą stać się miejscem uprawiania szczególnej twórczości dziennikarskiej, w której generalizowanie na podstawie epizodów, wątpliwych poszlak, wyznań niewiarygodnych świadków, nieuprawnionych analogii, służących kreowaniu wydarzeń, jest ważniejsze od ich przedstawiania, analizowania, syntetyzowania oraz wyjaśniania i prognozowania ${ }^{1}$.

Tego rodzaju zachowanie mediów może być postrzegane jako wyraz pewnej formy absolutyzmu normatywnego, aksjologiczno-etycznego oraz jako mechanizm kolektywnej dominacji ${ }^{2}$, marginalizacji ${ }^{3}$ i przemocy symbolicznej ${ }^{4}$, którego zamierzeniem jest wykreowanie człowieka sformatowanego. W ten sposób funkcja ceremonialna czy rytualna mediów, odgrywających rolę jedynego sprawiedliwego, ma się jak na razie bardzo dobrze, bowiem odpowiada potrzebom zarówno przeciętnego odbiorcy, jak i samym w większości skomercjalizowanym mediom. Dlatego swoisty rytuał interakcyjny mediów ${ }^{5}$, jaki zachodzi między nimi a odbiorcami, zwraca uwagę na cechy mediów jako podmiotów dynamicznie reagu-

1 Szerzej na ten temat zob. M. Lisowska-Magdziarz, Analiza tekstu w dyskursie medialnym, Kraków 2006.

2 J. Wasilewski, Retoryka dominacji, Warszawa 2006.

3 Przemoc i marginalizacja. Patologie społecznego dyskursu, red. P. Piotrowski, Warszawa 2004.

4 Formy przemocy w kulturze współczesnej, red. H. Mamzer, Poznań 2006. 
jących na zmieniające się okoliczności oraz świadomych swych możliwości kreujących rzeczywistość ${ }^{6}$.

Media mogą być wówczas traktowane jako organizacje wytwarzające serie powtarzających się interakcji, których efektem obok realistycznych obrazów rzeczywistości (zbudowanych na podstawach tak zwanej solidarności mechanicznej) są swoiste abstrakcyjne formy przedstawień zbiorowych (odzwierciedlających tak zwaną solidarność organiczna). Ten pierwszy rodzaj kultury medialnej reprezentuje nurt przekazów tabloidalnych, skupiających się na konkretnych, realistycznych czy nawet naturalistycznych przedstawieniach oraz zreifikowanej symbolice, stanowiącej wyraz prostego podziału pracy i ograniczonej sieci interakcji społecznych. Natomiast drugi nurt swoistej kultury medialnej wyrażają przekazy bazujące na formach abstrakcyjnych, które wynikają z zaawansowanego podziału pracy oraz szerokiej i zróżnicowanej sieci interakcji społecznych. Taki rodzaj medialnego przekazu posiada na ogół charakter intelektualny lub mentalny, oparty na emocjach i wrażeniach. Jego rezultatem jest relacja symboliczna, rozmyta, polisemiczna, zwykle prowokująca również do zróżnicowanych i wzajemnie wykluczających się interpretacji ${ }^{7}$.

Powyższy przykładowy podział kultury medialnej na dwa charakterystyczne typy, wyodrębnione na podstawie właściwego im sposobu konceptualizacji rzeczywistości, korzysta z tak zwanej zasady zróżnicowania społecznego Randalla Collinsa ${ }^{8}$, na której podstawie nadawcy przekazów statuują je w kategoriach dóbr zaspokajających potrzeby wyodrębnionych kategorii społecznych. Media pełnią wówczas głównie funkcję komercyjno-utylitarna. W warstwie semantycznej propozycja ta jest zbieżna z wynikami badań Basila Bernsteina i jego teorią kodu ograniczonego (prostego) i rozwiniętego (złożonego) ${ }^{9}$. W tym systemie

${ }^{5}$ E. W. Rotenbuhler, Komunikacja rytualna. Od rozmowy codziennej do ceremonii medialnej, Kraków 2003.

${ }^{6}$ E. Bobrowska, Obrazowanie społeczeństwa w mediach. Analiza radiomaryjnego dyskursu, Kraków 2007; Prawne, ekonomiczne i polityczne aspekty funkcjonowania mediów i kreowania ich zawartości, red. P. Dudek, M. Kusia, Torun 2010.

7 D. Dobrzański, Interpretacja jako proces nadawania znaczeń. Studium z etnometodologii, Poznań 1999.

8 Zob. R. Collins, Łańcuchy rytuatów interakcyjnych, Kraków 2011.

9 Zob. B. Bernstein, Class, Codes and Control, London 1975; idem, Socjolingwistyka a społeczne problemy kształcenia, w: Język a społeczeństwo, red. M. Głowiński, Warszawa 1980, s. 95-115. 
media mogą być postrzegane głównie w kategoriach funkcji socjalizacyjno-manipulacyjnej.

W ramach charakterystycznych językowych sposobów konceptualizacji rzeczywistości, odpowiadających powyższym podziałom, występują zarówno pojęcia odzwierciedlające realny świat (opisują fakty, rzeczy, zdarzenia), jak i pojęcia abstrakcyjne (dotyczą wyobrażeń, idei, wizji), w tym także pojęcia o charakterze teoretycznym oraz spekulatywnym, czyli o niejednoznacznym statusie poznawczym. Niestety wraz $\mathrm{z}$ tymi ostatnimi pojawiają się $\mathrm{w}$ przestrzeni medialnego dyskursu politycznego także stereotypy, mity, uprzedzenia, supozycje, generalizacje ${ }^{10}$. Rzadziej towarzyszą im postawy racjonalne, oparte na faktualności, natomiast częściej irracjonalne, bazujące na pozaempirycznej oraz abstrakcyjnej konceptualizacji wypowiedzi, zdarzeń, zjawisk. Ich celem na ogół nie jest rzetelne przedstawienie i wyjaśnienie rzeczywistości, lecz jej charakterystyczna twórcza interpretacja, przeobrażenie i wykreowanie, zmierzające na ogół do utrwalenia istniejących podziałów społecznych bądź wywołania nowych.

Jest to przykład między innymi myślenia bipolarnego (przeciwieństwo myślenia pluralistycznego), którego skutkiem jest zachowanie zmierzające zarówno do systematycznej polaryzacji opinii publicznej, jak również do jej odpowiedniej segregacji, bazującej na wykreowanym obrazie świata ${ }^{11}$. Dlatego w warstwie semantycznej takich wypowiedzi zamiast o ich denotacyjnej funkcji, skupionej na odzwierciedleniu rzeczywistości, lepiej mówić o funkcji konotacyjnej, a więc łączącej się bardziej z doświadczeniem kulturowym danej osoby, jej charakterystycznymi poglądami na świat oraz aktualnymi interesami i celami politycznymi. Problematykę tę w ramach językowego obrazu świata podnosił wielokrotnie Jerzy Bartmiński, zauważając: Jeśli w semantycznej definicji wyrazu nie uwzględni się cech zaliczanych zwykle do konotacji semantycznej, wówczas zagubiona zostanie np. semantyczna motywacja większości wyrazów polisemicznych, język stanie się totalnie homonimiczny. W każdym więc wypadku postulować należy koncepcję znaczenia rozszerzonego, uwzględniajacego zarówno znaczenie leksykalne, jak i konotację semantyczna ${ }^{12}$.

10 J. Majewski, Religia, media, mitologia, Gdańsk 2010.

11 Kreowanie światów w języku mediów, red. P. Nowak, R. Tokarski, Lublin 2007.

12 J. Bartmiński, Językowe podstawy obrazu świata, Lublin 2009, s. 75. 
Zdecydowanie innym typem wypowiedzi są wyrażenia performatyw$n \mathrm{e}^{13}$. Realizując określone intencjonalne działania werbalne, tworzą nowe pozajęzykowe stany rzeczy ${ }^{14}$. Performatywy nie mając charakteru opisującego, nie są ani prawdziwe, ani fałszywe. Należą do tej kategorii na przykład takie zwroty, które pojawiają się w wypowiedziach polityków, jak: „to jest prawda”, „musimy z tym zrobić porządek”, „dość tego gadania, czas się wziąc do roboty”, „nie dotrzymujecie słowa”, „dawno sytuacja nie była tak zła”. Służą one głównie potwierdzeniu wcześniej wygłoszonej myśli. Jak widać performatywy odnoszą się nie do realnego bytu, lecz do zdań opisowych, zawierających ocenę bądź wartościujących rzeczywistość (także pod względem etycznym).

W medialnym obrazie rzeczywistości performatywy odgrywają fenomenalną afektywną rolę. Statuują bowiem podmiot na pozycji wojownika - co ludziom się na ogół podoba. Dlatego zwykle nie zwraca się uwagi na status poznawczy aktów performatywnych, chociaż warto, nie przekazują one bowiem żadnej nowej informacji o realnym świecie, a jedynie tworzą fakty społeczne. Te zaś prawie doskonale wręcz nadają się do mediów: semantycznie są polisemiczne, społecznie jednak nośne. Są często przywoływane, interpretowane, komentowane w mediach. Do aktów performatywnych zalicza się w szczególności: asercje (zawierają sądy), akty ekspresywne (wyrażają stany emocjonalne), akty dyrektywne (wywierają nacisk na odbiorcę), akty komisywne (zmierzają do podjęcia działania lub zobowiązania), akty deklaratywne (tworzą nowy stan rzeczy).

Warto w tym miejscu zwrócić także uwagę na uwarunkowania przedjęzykowego obrazowania rzeczywistości w mediach. Jak widać na powyższych przykładach, podmiot poznający jeszcze przed próbą medialnego zobrazowania rzeczywistości zwykle już dysponuje określonym paradygmatem poznawczo ją statuującym w konkretnych ramach mentalno-intelektualnych, między innymi o charakterze ideologiczno-aksjologicznym i moralnym (odpowiadających określonym poglądom, wartościom, wzorcom, normom). Można go sprowadzić do swoistego medialnego sądu

13 J. L. Austin, Mówienie i poznawanie. Rozprawy i wyktady filozoficzne, Warszawa 1993.

${ }^{14}$ Szerzej o związku intencjonalności i znaczenia zob. M. Maciejczak, Intencjonalność i znaczenie językowe, Wydawnictwo Uniwersytetu Kardynała Stefana Wyszyńskiego 2010. 
a priori o rzeczywistości, chociaż ufundowanego przecież na wcześniejszych doświadczeniach, wyobrażeniach, przesądach.

$\mathrm{Na}$ to zaś nakłada się specyfika warsztatu danego medium, której zadanie sprawdza się do odpowiedniego sformatowania przekazu. Dlatego niemniej ważnym czynnikiem warunkującym specyficzny medialny obraz rzeczywistości politycznej są dziennikarskie elementy warsztatowo-pragmatyczne. Kierują one naszą uwagę na własności i swoiste cechy danego medium, a wraz z nimi na techniczno-technologiczne możliwości mediów, wykorzystywane w procesie medialnego kreowania i obrazowania rzeczywistości. Ich rezultatem może być nie tylko zróżnicowany obraz rzeczywistości, lecz również obraz zmanipulowany, wykorzystujący elementy zarówno językowe ${ }^{15}$, jak i towarzyszącą im formę prezentacji ${ }^{16}$.

W tym kontekście poznawczym można mówić zarazem o treści danego obrazu świata, jak i formie jego przedstawienia. Znaczenie formy, zwłaszcza w przekazie audiowizualnym, w niektórych sytuacjach, zwłaszcza tam, gdzie występują silne awersje i podziały społeczne, może być większe od jej literalnej, zwykle językowej treści. Jest to potwierdzeniem olbrzymiej roli genetycznego, obrazowego (naocznego) sposobu odbioru rzeczywistości przez człowieka, dla którego sugestywność pierwotnej formy ikonograficznego przedstawienia znajduje się przed jej wtórną językową konceptualizacją. Pomimo, że wymiarami współczesnej kultury medialnej sa, poza logosferą (mowa, tekst), fonosfera (dźwięk) oraz ikonosfera (obraz), to ta ostatnia zdecydowanie góruje nad pozostałymi pod względem wpływu na odbiorców oraz ich zainteresowania.

Efektem takich przekazów jest zapośredniczony medialnie obraz rzeczywistości, któremu na ogół nie brakuje podejścia indukcyjnego, to znaczy takiego, które skupiając się na obserwowaniu faktycznych przejawów zdarzeń społecznych, nie tylko dąży do odkrycia regulującego go porządku, lecz także wyjaśnia go za pośrednictwem określonej teorii lub praktyki, przyjętej w procesie medialnej konceptualizacji rzeczywistości. W ten sposób dziennikarze postępują zgodnie z triadą: empiria - rozum i warsztat - przekaz. Ułomnością takiego przekazu jest zwykle

15 Manipulacja w języku, red. P. Krzyżanowski, P. Nowak, Lublin 2004.

16 M. Mrozowski, Między manipulacja a poznaniem. Człowiek $w$ świecie mass mediów, Warszawa 1991; Przegląd technik manipulacji mediów, red. G. Abramczyk, Warszawa 2006. 
skupianie się na faktycznym jednostkowym zdarzeniu, czyli swoista incydentalność i odpowiadająca mu faktograficzność przekazu.

Taki przekaz medialny nie jest w stanie pokazać szerszego rzeczowego kontekstu wydarzenia, tym samym podnieść na przykład problematyki procesualnej natury zjawisk społecznych. Zaś w szczególności odnieść się do takich abstrakcyjnych, lecz niemniej ważnych czynników konstytuujących społeczeństwo, jak idee, wartości, wzorce, normy, role, a zwłaszcza relacje społeczne. Te ostatnie, kładąc nacisk na aspekt wzajemności, czyli interakcji kooperacyjnych między ludźmi, stanowią ważny środek objawiania się postaw, wzorców i norm społecznych oraz świadczą o wartościach motywujących zachowania społeczne. Jak zauważa S. Ehrlich: Z chwila kiedy wartości uzewnętrzniaja się w zachowaniu społecznym [...] moga się stać przedmiotem badań empirycznych zarówno $w$ aspekcie postaw $i$ motywacji, jak $i$ sposobu ich realizowania ${ }^{17}$. Zatem objawianie się tych elementów wraz ze sposobem ich pokazywania w sferze publicznej wiele mówi o rodzaju i poziomie danej kultury społecznej i politycznej, także kultury medialnej.

W rezultacie jednak skupienie się na zewnętrznym wymiarze konkretnego wydarzenia, które jest przejawem działania społecznego, jest dla mediów wygodne. $Z$ tej między innymi przyczyny, że z punktu widzenia poznawczego i warsztatowego jest stosunkowo proste ${ }^{18}$. W odróżnieniu od relacji społecznej, która jest na ogół złożona, cechuje się płynnością oraz aktualizuje na drodze kooperacji, zarówno pozytywnej, jak i negatywnej, konfliktogennej.

Obrazując zróżnicowanie społeczne i towarzyszące mu podziały społeczne, media stanowią trwały i ważny element kultury społecznej. W rezultacie stają się również częścią tak zwanej kultury popularnej ${ }^{19}$, której szczególnymi przedmiotami zainteresowania są współcześnie seksualność i erotyka oraz groza i przemoc ${ }^{20}$. Jej istota jest zaspokajanie potrzeb przeciętnego odbiorcy, którego charakterystyczną cechą jest

17 S. Ehrlich, Wiażace wzory zachowania. Rzecz o wielości systemów norm, Warszawa 1995, s. 27.

18 D. Dajan, E. Katz, Wydarzenia medialne. Historia transmitowana na żywo, Warszawa 2008.

${ }_{19}$ Kultura popularna $w$ społeczeństwie wspótczesnym. Teoria i rzeczywistość, red. J. Drozdowicz, M. Bernasiewicz, Oficyna Wydawnicza IMPULS 2009.

20 M. Kamińska, A. Horowski, Erotyzm, groza, okrucieństwo - determinanty współczesnej kultury, Poznań 2008. 
bierna partycypacja, ograniczająca się do odbioru danego przekazu kulturowego $^{21}$. W dziedzinie obrazowania rzeczywistości politycznej skomercjalizowane media posługują się więc również narzędziami i tropami właściwymi dla kultury popularnej, którą także w ten sposób współtworzą i reprodukują, oferując gotowe wzory kulturowe ${ }^{22}$. Rezultatem ich działalności jest dyfuzja kulturowa, która polega na rozprzestrzenianiu się za pośrednictwem mediów szeroko rozumianych produktów kulturowych oraz wzorów kulturowych, charakterystycznych dla danego kręgu kulturowego ${ }^{23}$. W rezultacie media nie tylko pośredniczą między szeroko rozumianymi wytworami kultury i odbiorcami ${ }^{24}$, ale same stają się kulturą o określonych preferencjach, wzorach, wartościach, cechach, normach $^{25}$. W ten sposób mogą odgrywać ważną i pozytywną rolę także w innych dziedzinach życia, jak na przykład w budowaniu kapitału społecznego ${ }^{26}$.

W ten sposób media również partycypują w dziele socjalizacji wtór$n^{27}{ }^{27}$, w której ich rola jest coraz większa ${ }^{28}$. Zwiększa się bowiem konsumpcja mediów, ograniczając tym samym udział w socjalizacji takich tradycyjnych czynników, jak rodzina, religia czy szkoła. Skutkiem oddziaływania mediów na socjalizującą się jednostkę jest obok wzrostu jej samoświadomości ${ }^{29}$, również wpływ na jej wychowanie ${ }^{30}$ oraz kształt tożsamości, zarówno osobowej (zapewnia ciagłość jaźni, własnego ist-

21 Szerzej na ten temat zob. A. Kłoskowska, Kultura masowa. Krytyka i obrona, Warszawa 1983; idem, Socjologia kultury, Warszawa 1981.

${ }^{22}$ W interesujący sposób pisze o tym D. Piontek, Komunikowanie polityczne i kultura popularna. Tabloidyzacja informacji o polityce, Poznań 2011.

23 E. Leach, Kultura i komunikowanie, Warszawa 2010.

24 Kultura medialnie zapośredniczona. Badania nad mediami w optyce kulturoznawczej, praca zbiorowa, Poznań 2010.

25 W. Godzic, Telewizja jako kultura, Kraków 2002.

26 C. Jerzmanowski, Media a rozwój gospodarki i kultury. Budowanie kapitału społecznego, Zamość 2004.

27 Proces socjalizacji zachodzi poprzez naśladownictwo, identyfikację, wychowanie oraz świadome decyzje jednostki i dokonuje się dzięki interakcjom społecznym, w tym kontaktom z mediami. Proces socjalizacji wtórnej ma miejsce w wieku dorosłym. Realizuje się przez akty samej jednostki, która wchodząc w określone interakcje społeczne nie tylko kształtuje i rozwija samoświadomość, lecz również tożsamość.

28 B. Dziadzia, Wplyw mediów. Konteksty społeczno-edukacyjne, Kraków 2007.

29 J. Gajda, Edukacja bez granic. O środkach masowego przekazu, Lublin 1992.

30 M. Musioł, Media w procesie wychowania, Torun 2006. 
nienia), jak i społecznej (daje poczucie określonego statusu społecznego i roli społecznej $)^{31}$. Tożsamość jednostki nie jest stała, jednorodna, lecz podlega negocjowaniu ${ }^{32}$. Duży wpływ na zmianę tożsamości mają bezpośrednie kontakty interpersonalne oraz pośrednie oddziaływanie mediów (paraspołeczna interakcja między odbiorcą a nadawcą ${ }^{33}$ ), a także szeroko rozumiane predyspozycje jednostki (doświadczenie, wiedza, charakter, osobowość, cele, motywacje, postawy, zachowanie, sposób życia). Między innymi w wyniku inspiracji mediów tożsamość jednostki ulega transformacji, a więc zmianie i modyfikacji. Wyróżnia się transformację totalną (obejmuje zmianę całego światopoglądu i systemu wartości) oraz transformację częściową (dotyka tylko wybranych elementów dotychczasowej tożsamości) ${ }^{34}$.

Jeżeli uznamy, że życie psychiczne człowieka (w tym takie elementy, jak: wyobraźnia, wzorce, normy, wartości, symbole, moralność, poglądy, postawy) stanowi w całości produkt oddziaływania społeczeństwa, to uznamy również wpływ mediów na życie psychiczne człowieka za niepodważalny, bowiem media są współcześnie ważnym funkcjonalnym elementem społeczeństwa. Zatem w procesie objaśniania i wyjaśniania złożonej rzeczywistości politycznej dziennikarze nie powinni się kierować tylko podejściem naturalistycznym, zwracając uwagę głównie na tzw. zewnętrzną stronę rzeczywistości, lecz powinni odwoływać się do wartości ${ }^{35}$, przekonań, postaw, idei, zamiarów, jakimi ludzie się kierują, dokonując stosownych wyborów politycznych ${ }^{36}$. W ten sposób dziennikarz, biorąc pod uwagę dyrektywę tzw. podejścia humanistycznego lub wskaźnika humanistycznego, może odkryć, jak to, co obserwuje [...],

31 Z. Bokszański, Tożsamość, interakcja, grupa, Łódź 1989, s. 12; idem, Tożsamości zbiorowe, Warszawa 2005.

32 J. Mikułowski Pomorski, Rola mediów w negocjowaniu tożsamości, w: Tożsamość polska w odmiennych kontekstach, red. L. Dyczewski, D. Wadowski, Lublin 2009.

33 Szerzej na ten temat zob. Psychologiczne aspekty odbioru telewizji, red. P. Francuz, Lublin 1999.

34 E. Hałas, Konwersja. Perspektywa socjologiczna, Lublin 1992, s. 86 i n.

35 M. Ejsmont, B. Kosmalska, Media, wartości, wychowanie, Kraków 2005; J. Jastrzębski, Na rynku wartości. O mediach i etyce dziennikarskiej, Wrocław 2009.

36 Zauważył to na przykład F. Znaniecki, pisząc: Ludzie będacy uczestnikami zbiorowości nie sq bowiem jedynie organizmami biologicznymi: świadomie myśla i działaja [...]. Nie da się wyjaśnić tego, co robia, ani przewidzieć, jak postapia, nie rozważywszy szczegółowo ich idei, przekonań, postaw oraz aktywnych dażności (Relacje społeczne i role spoteczne, Warszawa 2011, s. 63). 
jest doświadczane i oceniane przez tych działajacych ludzi, którzy sq tym czymś aktywnie zainteresowani. [...] I w toku tego podejścia [...] odkryje, że oceny i czynności świadomie działajacych ludzi nie sq determinowane przez nature, ale uwarunkowane kulturowo ${ }^{37}$.

Konsekwencją tego podejścia jest traktowanie mediów jako swoistego dokumentu obrazującego doświadczanie zbiorowe rzeczywistości politycznej i jej ocenę. Tym samym otrzymamy dane umożliwiające, jeżeli nie odtworzenie rodzaju kultury, jaka występuje w danej społeczności czy społeczeństwie, to przynajmniej obraz jej cech charakterystycznych. Obrazem tej kultury jest bowiem między innymi język, także język polityki i język o polityce, który generuje różne sposoby konceptualizacji i przedstawiania świata ${ }^{38}$.

W procesie obrazowania rzeczywistości zawarte jest explicite założenie twórczości, której skutkiem jest swoisty medialny obraz rzeczywistości $^{39}$. Zatem sama twórczość dziennikarska polegająca na obrazowaniu rzeczywistości, której efekt zwykle przedostaje się do wiadomości publicznej (jawna strona procesu informowania) oraz jej złożone uwarunkowania (niejawna strona procesu informowania), w tym także dziennikarska selekcja informacji przeznaczonych do rozpowszechniania (gatekeeping) oraz tak zwane ramowanie informacji (framing) ${ }^{40}$, mogą być przedmiotem oddzielnej analizy i refleksji zarówno medioznawczej, jak i ontologicznej oraz epistemologicznej.

Specyfika twórczości dziennikarskiej skupiającej się na polityce polega na tym, że jej narzędzia, którymi są zarówno selekcja i ramowanie materiału przeznaczonego do emisji, jak i zestaw językowych oraz technicznych środków kreowania na tej podstawie obrazu świata, prowadzą do przekazu z perspektywy teoriopoznawczej niedookreślonego, w którym różnica między pewnością a prawdopodobieństwem jest niezmiernie płynna. W złożonym bowiem procesie kreowania wykorzystywane są nie tylko fakty i ich związki, lecz także charakterystyczne sposoby

37 Ibidem, s. 64.

38 I. Hofman, Polityka, media, społeczeństwo. Studia i szkice, Torun 2007.

39 Ciekawe rozważania na ten temat prezentuje P. Przywara, News a fakt-wokót relacji między medialnym obrazem świata a rzeczywistościa, http://pawelprzywara.wordpress.com/2011/11/06/news-a-fakt-\%E2\%80\%93-wokol-relacji-miedzy-medialnym-obrazem-swiata-a-rzeczywistoscia/ (6.11.2011).

40 Szerzej na temat analizy ramowej i ramowania zob. T. Olczyk, Politrozrywka i popperswazja. Reklama telewizyjna $w$ polskich kampaniach wyborczych XXI wieku, Warszawa 2009, s. 229-279. 
konceptualizacji rzeczywistości właściwe danemu autorowi oraz zbieżne $\mathrm{z}$ linią programową redakcji ${ }^{41}$.

Dlatego na gruncie teoriopoznawczym nie jest możliwe utożsamianie faktualnej prawdy o rzeczywistości z prawdą medialną ${ }^{42}$. W świecie polityki i w procesie medialnego obrazowania polityki prawda faktualna - rozumiana w kategoriach deskryptywnych - jest wypierana przez konstruowanie znaczenia, jakie nadaje się danym faktom i ich związkom. W wyniku twórczej operacjonalizacji medialnej pierwotny fakt nie jest już tym samym faktem, lecz wykreowanym znaczeniem medialnym. Zatem także treść faktu nie jest już znakiem czegoś, lecz odgrywającym jaką́s rolę znaczeniem, które ma status drugiego faktu - swoistego metafaktu. To zaś prowadzi do powstania nowego wtórnego bytu o określonym znaczeniu komunikacyjnym, który ma także inną funkcję społeczną i polityczną od faktu pierwotnego. W ten sposób pojęcie „znaczenia” jest statuowane poznawczo jako pojęcie relacyjne (odnoszone zarówno do przedmiotu, jak i podmiotu) i relatywne (względne, uwarunkowane). To znaczy, że jest ono również wyrazem relatywizmu poznawczego, a zatem także konwencjonalne i intencjonalne, również $\mathrm{w}$ dziedzinie aksjologii i moralności. W komunikacji publicznej ma to niebagatelne konsekwencje, utrudnia bowiem sam proces porozumiewania się. Dlatego na gruncie różnych znaczeń, odwołujących się do tych samych desygnatów, trudno jest znaleźć porozumienie.

W ten sposób w ramach rozważań medioznawczych nad procesem obrazowania rzeczywistości politycznej przez media możemy również mówić o swoistej psychologii oraz pedagogice mediów. W konsekwencji także o ich osobniczych funkcjach, na przykład: edukacyjno-wychowawczej, eksplanacyjnej, estetycznej, kulturowej, informacyjnej, publicystycznej, politycznej, ekonomicznej, poznawczej, dokumentalnej. Status danej funkcji zależy zwykle nie tylko od autonomicznej decyzji danego podmiotu medialnego, ale także od specyficznych potrzeb społecznych oraz złożonych uwarunkowań między innymi prawnych, społecznych, politycznych, kulturowych, a nawet obyczajowych, jakie występują w danym kraju, regionie czy społeczności.

41 W. Gałązka, Gotowych faktów nie ma. Kreacja informacji oraz wizerunku publicznego i medialnego, Wrocław 2008; W. Jabłoński, Kreowanie informacji. Media relations, Warszawa 2006.

42 Dziennikarz - między prawdq a kłamstwem, praca zbiorowa, Łódź 2009. 


\section{Rzeczywistość polityczna w mediach}

Problematyka polityczna zajmuje ważne miejsce w ogólnoinformacyjnym przekazie medialnym. Dzieje się tak nie tylko z tego powodu, że ona sama przez się stanowi dla dziennikarzy wdzięczny obiekt zainteresowania, lecz również z tej przyczyny, że problematyka ta obejmuje zwykle sferę publiczną, zatem wspólną, czyli dotyczącą potencjalnie każdego mieszkańca, w szczególności obywatela.

W strumieniu zróżnicowanych informacji medialnych wydarzenia polityczne na ogół znajdowały się na czołowym miejscu i odgrywały ważną rolę nie tylko w mediach publicznych, ale także w mediach komercyjnych. Była ona zwykle pochodną ważności wydarzenia (mierzonej bezwzględną skalą jego społecznej doniosłości) oraz jego atrakcyjności medialnej (gdzie obowiązywała względna, medialna skala wartości wydarzenia). Nie zawsze ważność wydarzenia jest wprost proporcjonalna do jego atrakcyjności medialnej, która na ogół opiera się na elementach intrygujących, wywołujących dysonanse, czy nietypowych. W wielu przypadkach było odwrotnie, co jest wyrazem natury współczesnych mediów skupionych raczej na medialności wydarzenia, a nie na jego społecznej ważności.

Tę swoistą konieczność mediów zaspokajały materiały ze sfery politycznej dotyczące takich zjawisk, sytuacji, zdarzeń, wypowiedzi, które posiadały nie tylko szeroki zakres praktyczny i publiczny, gdy dotyczyły całości społeczeństwa lub przynajmniej dużej jego części, i wyrażały faktyczne egzystencjalne potrzeby ludzi. W szczególności takie materiały, które posiadając charakter krytyczny, polemiczny, aferalny, napastliwy, złośliwy, agresywny bądź tragiczny, losowy, przypadkowy, służły mediom nie tylko do informowania oraz eksplikowania rzeczywistości, ale nade wszystko do jej wyraźnej i jednoznacznej klasyfikacji. W ten sposób media nie tylko przedstawiały i wyrażały określone podziały polityczne oraz ideologiczne, pokazując przykłady polaryzacji w dziedzinie zachowań oraz wyborów aksjologiczno-moralnych, ale także poddawały je określonej ocenie. Jej wyrazem była polemika (oznaczająca poznawczo stosunkowo miękkie podejście do obrazowanego tematu), krytyka (stanowiąca poznawczo wyraz twardego stosunku mediów do rzeczywistości), pochwała bądź zachowanie neutralne.

Z perspektywy mediów materiały polemiczne i krytyczne łatwo statuowały się w zwykle dychotomicznej dziennikarskiej skali dobra i zła, prawdy i kłamstwa, aktywności i bierności, odpowiedzialności i braku 
odpowiedzialności, gdzie przedstawienie wydarzenia czy problemu często zawężano do pokazania przeciwstawnych sądów na jego temat. Do tej kategorii postawy należy sławetne w Polsce emfatyczne skupianie się na poszukiwaniu winnych, nie zaś przyczyn czy motywów zdarzeń ${ }^{43}$. $\mathrm{W}$ ten sposób dziennikarze dysponowali interesującym $\mathrm{z}$ ich punktu widzenia materiałem, który zwykle nie mógł obiektywizować rzeczywistości ${ }^{44}$, a tym bardziej rozwiązywać pojawiających się wraz z nią problemów, lecz przynajmniej umożliwiał odbiorcom zajęcie skrajnych i w zasadzie wykluczających się stanowisk. To zaś wywoływało na ogół zwiększone zainteresowanie społeczne nie tylko określonym medium, lecz także wydarzeniem, a zwłaszcza inkryminowaną osobą, reprezentującą zwykle jakąś partię, organ władzy czy administracji publicznej. Takie materiały dziennikarskie o polityce wzbudzają emocje społeczne i dychotomizują opinię publiczną. Służą tym samym przyciągnięciu uwagi odbiorców. Jednak zwykle obniżały stosunkowo płynny poziom integracji społecznej oraz dyspozycji zachowań i postaw koncyliacyjnych, kooperacyjnych oraz tolerancyjnych.

43 Nieco ironicznie odniósł się do tego problemu felietonista „Rzeczpospolitej” M. Rybiński, pisząc: Wszystko, co się dzieje, wszystko, co jest, a także to, czego nie ma, jest, zdaniem ludzi w ogóle, a Polaków w szczególności, rezultatem funkcjonowania jakiejś siły sprawczej. Jest to na ogół wraża, wroga i złośliwa siła, uniemożliwiajaca nam wszystkim razem i każdemu z osobna szczęśliwe bytowanie pozbawione troski. Stad pytanie: - Kto jest winien? Odpowiedzi na to pytanie sq sola, jadrem zycia politycznego i intelektualnego $w$ Polsce, podstawa organizowania się ruchów społecznych i ugrupowań politycznych. Różne sq definicje polityki. Moja własna, która, mam nadzieję, potomni nazwa definicja Rybińskiego, brzmi: Polityka jest to szukanie $i$ znajdowanie winnych (Definicja Rybińskiego, „Rzeczpospolita” 2003, 30.06, nr 150, s. A2).

44 Obiektywizacja nie jest rozumiana tutaj w kategoriach uzewnętrzniania wrażeń ludzi, w tym dziennikarzy, chociaż po części ma ona taki właśnie charakter, kiedy dopytujemy się o odczucia ludzi, ich opinie czy oceny. Tutaj pojęcie dziennikarskiej obiektywizacji rzeczywistości jest widziane w kategoriach próby ukazania rzeczywistych przyczyn, podstaw, skutków, związków, motywacji, czyli rzeczywistego stanu rzeczy. Dziennikarz nie posiłkuje się tylko wyobrażeniami, wrażeniami, urojeniami, które chociaż mają wartość obiektywną, nie mają jednak pozasubiektywnego przedmiotu odniesienia. Zatem dziennikarska obiektywizacja rzeczywistości jest próbą jej często żmudnego odkrywania i jako taka właśnie nie jest dana dziennikarzowi, lecz raczej zadana. W ten sposób służy zdobywaniu częściowej wiedzy o świecie. Na temat statusu tzw. wiedzy medialnej zob. J. Pleszyński, Wiedza medialna i jej status, w: Współczesne media. Status, aksjologia, funkcjonowanie, t. I, red. I. Hofman, D. Kępa-Figura, Lublin 2009, s. 293-303. 
W centrum dziennikarskiego zainteresowania na trwale znajdował się konkretny, zwykle pokazany w czasie teraźniejszym bądź przeszłym człowiek (nie zjawisko czy złożony proces, ukazane na tle genezy, przeobrażeń, etapów, ewolucji, prognoz) z jego na ogół subiektywną ${ }^{45}$, często również interesowną i nieracjonalną opinią czy oceną określonego stanu rzeczy. Jego stanowisko z reguły konfrontowano z przeciwstawnymi opiniami i ocenami innych osób. W rezultacie na uboczu dziennikarskiego zainteresowania problematyką polityczną, jak już wspomniano, pozostawała na ogół próba obiektywizacji rzeczywistości oraz udzielenia odpowiedzi na racjonalne pytania, choćby cząstkowe, o przyczynę, podstawy formalne, istotę, sens, a zwłaszcza konsekwencje określonych zachowań, zjawisk, wydarzeń. Dlatego charakterystyczną cechą takiego przekazu medialnego jest między innymi:

1) zjawiskowość, gdzie uwaga odbiorcy jest skupiona na widowiskowym szczególe, zwykle zindywidualizowanym i spersonalizowanym oraz mającym charakter rozrywkowy ${ }^{46}$;

2) niedostatek obiektywnego spojrzenia na rzeczywistość, które przecież nie może się zawężać do prezentacji skrajnych opinii oraz wrażeń na dany temat;

3) zubożenie problematyzacji prezentowanego zagadnienia, która jest wypierana przez zjawiskowość, subiektywizm, a wraz z nim wrażeniowość oraz indywidualizację wydarzenia;

45 Subiektywizm w naszym rozumieniu nie jest wadą osoby, lecz naturalnym sposobem jej wyrażania się, zwłaszcza w dziedzinie opinii, poglądów, sympatii, ocen. Dlatego tutaj subiektywizm oznacza indywidualny, zwykle stronniczy stosunek do określonej rzeczywistości, w którym kierujemy się osobistymi zapatrywaniami i przekonaniami. W wersji skrajnej subiektywizm występuje jako idealizm subiektywny, według którego przedmiotem poznania są subiektywne doznania, nie zaś obiektywny świat. To zaś może prowadzić do relatywizmu, w którym każdy indywidualny sąd o rzeczywistości jest nie tylko uprawniony, lecz uprawomocniony i cieszący się uznaniem społecznym (permisywizm). W dziedzinie poznania relatywizm prowadzi do sceptycyzmu, zaś do konformizmu w sferze moralności.

46 Generalnie odbiorcy postrzegają współczesne media głównie jako środek dostarczania rozrywki. Dlatego przekazy polityczne mają również charakter rozrywkowy, bowiem rozrywka jest jednym z ważniejszych czynników przyciągających odbiorcę do mediów, nawet mediów o charakterze informacyjnym. Stąd też pojawił się nowy termin określający to zjawisko jako informacyjną rozrywkę: inforozrywkę (ang. infotainment). Zob. N. Postman, Zabawić się na śmierć. Dyskurs publiczny w epoce show-businesu, Warszawa 2006. 
4) personalizacja rzeczywistości, w której główną rolę odgrywają poszczególne osoby, w szczególności ich emocje, namiętności, oceny, którym towarzyszy język agresji ${ }^{47}$;

5) skupienie na konflikcie międzyjednostkowym oraz międzygrupowym, zwykle o charakterze politycznym, ekonomicznym, aksjologicznym, moralnym, utylitarnym, pragmatycznym ${ }^{48}$.

Koncentrowanie się mediów na konflikcie politycznym, chociaż widowiskowe, ze społecznie utylitarnego punktu widzenia wydaje się niecelowe. Albowiem już F. Znaniecki zauważył, że współdziałanie między uczestnikami ludzkiej zbiorowości jest niezbędne dla jej istnienia. Co więcej, badanie źródła konfliktów międzyjednostkowych wskazuje, że wiele z nich jest skutkiem wptywów zewnętrznych naruszajacych już istniejace wspótdziałanie, podczas gdy konflikt międzygrupowy zakłada bliskie wspótdziałanie $w$ obrębie każdej z grup, które weszły ze soba w konflikt ${ }^{49}$. Media mogą być i często są jednym z tych czynników zewnętrznych, który narusza owe pierwotne współdziałanie społeczne, zarówno międzyjednostkowe, jak i wewnątrzgrupowe, oraz towarzyszące mu więzi społeczne. Dlatego ich zakładaną z punktu widzenia dobra wspólnego funkcją powinna być raczej funkcja integracyjna, koncyliacyjna, więziotwórcza, a nie konfliktotwórcza, która podnosząc na ogół naturalne przecież różnice istniejące między ludźmi i ich wyborami politycznymi, charakteryzuje z tej właśnie nieuprawnionej perspektywy stosunki międzyludzkie. Chociaż z komercyjnego punktu widzenia takie zachowanie mediów jest w pełni uzasadnione, to z perspektywy interesu publicznego jest ono wątpliwe. Bowiem niszczenie więzi społecznej przez media może wzmagać poczucie lęku u odbiorców. Niszcząc więzi społeczne, które opierają się na zaufaniu społecznym, przyczyniamy się tym samym do rozszerzania nieufności między ludźmi. Ta zaś powoduje na ogół wzmożenie lęku. W ten sposób tworzy się „błędne koło” - lęk zwiększa dezintegrację społeczną, zaś dezintegracja społeczna zwiększa lęk.

W konsekwencji polityczny przekaz medialny nie zawsze umożliwia odbiorcy autentyczne zbliżenie się do rzeczywistości realnej (głównie

47 M. Peisert, Formy i funkcje agresji werbalnej. Próba typologii, Wrocław 2004.

48 B. Dobek-Ostrowska, Porozumienie czy konflikt? Politycy, media i obywatele $w$ komunikowaniu politycznym. Propaganda i PR $w$ polityce, kampanie wyborcze, marketing i reklama polityczna, Warszawa-Bielsko-Biała 2009.

49 F. Znaniecki, Relacje społeczne i role społeczne, op. cit., s. 22. 
w jej aspekcie racjonalno-rzeczowym, podmiotowo-przedmiotowym oraz przyczynowo-skutkowym), w której bodaj najważniejsze jest znalezienie racjonalnej odpowiedzi na podstawowe pytania egzystencjalne, w tym także dotyczące sposobów społecznego komunikowania (odnoszące się w szczególności do treści, formy oraz metody przedstawiania i wyjaśniania złożonej rzeczywistości).

Niemniej dziennikarze stojący na gruncie realizmu epistemologicznego, który faktyczną realność nadaje jedynie osobie ludzkiej wchodzącej $\mathrm{w}$ interakcje społeczne, umożliwiając odbiorcy spotkanie w rzeczywistości wirtualnej, zapewniają mu również nie tylko bezpośredni dostęp do swoiście zobrazowanej informacji oraz zapośredniczony medialnie wgląd do wydarzeń, lecz także osobnicze przeżycie zastępcze na bazie treści i formy przez nich w całości skonstruowanej ${ }^{50}$. Jest to specyficzny przekaz, w którym miejsce autentycznego oraz bezstronnego opisu i diagnozy rzeczywistości politycznej zajmuje jej swoiste kreowanie, wykorzystujące głównie argumenty o charakterze ideologicznym i emocjonalnym, a nie pragmatycznym i racjonalnym. Kreacjonizm współczesnych mediów jest dwuaspektowy, dotyczy bowiem z jednej strony ich odniesienia do rzeczywistych wydarzeń, z drugiej zaś wykreowania rzeczywistości na potrzeby mediów. Prowadzi to do powstania nowej rzeczywistości, a mianowicie rzeczywistości medialnej lub tak zwanego faktu medialnego. O ile pierwszy aspekt kreacjonizmu mediów jest zrozumiały, gdyż jest osadzony na podstawowej formule działalności mediów, jaką jest próba odwzorowania rzeczywistości i sformułowania na tej podstawie

50 Sytuacja ta może prowadzić do systematycznego ograniczania zdolności faktycznego uczestnictwa odbiorcy przekazu medialnego w złożonym systemie komunikowania społecznego, w szczególności w obszarze dialogu społecznego. Media dostarczając odbiorcy namiastkę realnego dialogu, w rezultacie zastępują go, stanowiąc rodzaj zastępczego przeżycia. W konsekwencji dzięki mediom może postępować proces uwiądu osobowych i zbiorowych umiejętności prowadzenia autentycznego dialogu społecznego, zarówno indywidualnego, jak i publicznego. W rezultacie media niejako odcinając odbiorcę od kontaktu społecznego, również wyznaczają mu pola bezpośredniego zainteresowania (ustalanie hierarchii ważności, porządku dziennego, strukturyzowanie i hierarchizowanie wiadomości, agenda-setting). W ten sposób media pełnią także funkcję nadawania statusu określonym postaciom, podmiotom, problemom, wydarzeniom. Tym samym mogą ograniczać zdolności odbiorców do szerszej autorefleksji poprzez ograniczanie wysiłku intelektualnego do odbioru, naśladowania i powielania przekazywanych treści medialnych. Zob. A. Gut, O relacji między myśla a językiem, Lublin 2009; M. McCombs, Ustanawianie agendy. Media masowe i opinia publiczna, Kraków 2008. 
odpowiedniego sądu medialnego. To drugi jego aspekt budzi poważne wątpliwości natury zarówno warsztatowej, jak i aksjologiczno-etycznej.

Rzeczywistość wirtualna ma wpływ na powstanie nowych faktów realnych, ponieważ zmieniając świadomość człowieka, zmienia również przynajmniej jego potencjalną dyspozycję w zakresie postawy i zachowania, a niekiedy wywołuje realną aktywność. Nie ulega wątpliwości, iż w ten sposób media uczestniczą nie tylko w procesie medialnie zapośredniczonej komunikacji społecznej, rozumianej jako wymiana informacji między dziennikarzami i ich interlokutorami, ale również w dialogu publicznym, w którym ich status poznawczy zmienia się. Obok przedmiotowego przekazywania oraz komentowania informacji pojawia się ich podmiotowe uczestnictwo $\mathrm{w}$ dialogu społecznym ${ }^{51}$. Wraz $\mathrm{z}$ nim również dyspozycja określonego zachowania się mediów, w tym także przyjęcia określonej postawy wobec polityki publicznej.

W tej dziedzinie ogromną rolę odgrywają takie czynniki, jak: interesy (związane ze statusem formalnoprawnym, rynkowym, społecznym, politycznym mediów), wartości i imponderabilia (wyznawane i preferowane $\mathrm{w}$ procesie przekazywania informacji i uczestnictwa mediów w dialogu społecznym) oraz przekonania (przeświadczenia o słuszności swoich poglądów politycznych, społecznych, ekonomicznych, religijnych).

W tym miejscu należy podnieść problematykę systemowej dualności współczesnych mediów, na których zawartość składają się materiały zarówno dziennikarskie, jak i reklama. Dla reklamodawców media komercyjne są wówczas sprzedawcami dostępu do publiczności. Stąd jednym z ważnych celów mediów jest pragnienie wykreowania takiej publiczności, która odpowiada interesom reklamodawców. Dlatego postępująca komercjalizacja mediów prowadzi do komercjalizacji informacji, ta zaś

51 Oczywiście podmiotowość uczestnictwa mediów w dialogu społecznym, która objawia się w określonych przekazach medialnych lub w strumieniu przekazów, nie ruguje z oglądu poznawczego problematyki ich uczestnictwa jako indywidualnych i zbiorowych podmiotów życia gospodarczego, politycznego, społecznego, kulturalnego, religijnego. Obie formy podmiotowości umożliwiają mediom występowanie w roli strony w sporze politycznym, zarówno pośrednio poprzez przekazy medialne, jak i bezpośrednio jako indywidualne i zbiorowe podmioty medialne - $\mathrm{w}$ tym także poprzez swoiste formy asocjacji, jak: fundacje, stowarzyszenia, związki pracodawców, związki branżowe (np. Izba Wydawców Prasy). W ten sposób media jako ważne ośrodki wpływu politycznego mogą być tym samym wykorzystywane $\mathrm{w}$ procesie propagandy, manipulacji, socjotechniki, lobbingu. 
do jej reifikacji jako przedmiotu wymiany towarowej na rynku usług konsumenckich. Także media, przekształcając odbiorców w przedmioty zwykle zawoalowanego, jednak świadomego i celowego ich oddziaływania, reifikują się. W rezultacie zawartość mediów jawi się jako wypadkowa interesów ich właścicieli, pracowników, reklamodawców, polityków oraz odbiorców. Łącznie czynniki te mogą mieć znaczący wpływ na pojawienie się w mediach swoistej kultury cynizmu i egoizmu, którą determinuje własny interes mediów jako systemów społecznych. Systemów samoodnoszących się, czyli autopojetycznych, w których funkcjonalne całości są bezpośrednim rezultatem procesów wewnątrzsystemowych, a nie czynników zewnętrznych, środowiskowych. Istotną rolę w tym procesie mogą także odgrywać standardy obowiązujące media, zarówno prawne i etyczne, jak warsztatowe oraz wynikające z samoregulacji mediów. Jest to dla systemu społecznego niezmiernie ważne, bowiem jak pisze P. Sztompka: W świecie bez standardów panuje nieufność, zachowanie innych jest bowiem arbitralne ${ }^{52}$. Co ma niemniej istotne znaczenie podczas relacjonowania przez media zarówno prawdziwych konfliktów społecznych, jak i wykreowanych. Kiedy interakcja między antagonistami nie podlega żadnym wspólnym normom i nie posiada żadnych podzielanych przez obie strony wzorców, konflikt może stać się catkowicie bezlitosny. Gdy zaś inni uczestnicy danej społeczności zajmuja strony $w$ takich konfliktach, społeczność może ulec częściowemu podziałowi na walczqce ze sobq frakcje, co z kolei ma dezorganizujacy wpływ na społeczność jako całość ${ }^{53}$.

W konsekwencji działalność mediów można również ujmować w kategoriach czynnika, który na arenie komunikacji publicznej zajmuje współcześnie pozycję dominującego wręcz środka oddziaływania, wpływu i sankcji nie tylko na zindywidualizowanego odbiorcę ${ }^{54}$, lecz szerzej

52 P. Sztompka, Zaufanie. Fundament społeczeństwa, Kraków 2007, s. 227.

53 F. Znaniecki, Relacje społeczne i role społeczne, op. cit., s. 122.

54 Odbiorca mediów może być wówczas postrzegany w kategoriach przedmiotu quasi zewnątrzsterowanego, podobnie zresztą jak całe społeczeństwo quasi zewnątrzsterowane. Przedrostek quasi oznacza tutaj niezgodę na uznanie wręcz majoryzującego wpływu mediów na odbiorców, lecz jest wyrazem poparcia dla akceptacji ich potencjalnej możliwości i skali takiego oddziaływania na odbiorców, które w ich pewnej części może powodować kierunkowe, zatem zgodne z dyspozycją mediów, zmiany postawy czy zachowania. W odniesieniu do pojęciowego ujmowania problematyki wpływu mediów na odbiorców możemy używać również stosunkowo neutralnej formuły „identyfikacji”, która zwraca uwagę na próbę naśladowania przez 
- na całą sferę publiczną, w tym na politykę, gospodarkę, kulturę. Media są wówczas postrzegane $\mathrm{w}$ perspektywie nie tylko środka artykulacji społecznej, lecz także agregacji społecznej. Ich podmiotowość społeczna, cechująca się możliwością świadomego podejmowania ukierunkowanych działań, jest niepodważalna. To zaś ma niebagatelne znaczenie w określaniu statusu ontologicznego i epistemologicznego mediów jako podmiotów publicznych oraz konstruowanych przez nie przekazów.

$\mathrm{W}$ rezultacie $\mathrm{z}$ perspektywy przedmiotowego traktowania mediów i ich przekazów przechodzimy do perspektywy ich podmiotowego uczestnictwa w życiu społecznym. Zatem również do problematyki kreowania oraz obrazowania rzeczywistości politycznej, która tworzy obszar wielostronnych asocjacji zarówno na gruncie ontologicznym, jak i epistemologicznym.

\title{
The media as a form of collective presentation of politics and its epistemological determinants
}

\begin{abstract}
Summary
The paper touches upon the issue of media behavior in the market of public communication and the epistemological determinants of the process of media imaging of political reality. Consequently, it becomes feasible to distinguish two types of messages: one focused on information and the other concentrated on overt or covert persuasion. Thus, the author emphasizes the ritual function of the media, which meets the needs of average recipients as well as those of commercialized media. Therefore a certain interaction ritual of the media that takes place between them and their audience points to the media as entities dynamically responding to changing circumstances and aware of their own potential to create reality.
\end{abstract}

odbiorcę wypowiedzi, gestów, postawy, wyglądu, zachowania, obyczaju, mentalności medialnych postaci oraz prezentowanych przez nie poglądów. 